\title{
Hilf sbüchlein
}

für den

\section{römischen Zivilprozess zum Gebrauch bei Vorlesung und Studium.}

\author{
Auf der Grundlage der \\ Vorlesungsbeilagen von O. Fischer und R. Schott \\ herausgegeben von \\ E. F. Bruck, O. Fischer, F. Klingmüller und R. Schott.
}

\section{Vierte Aullage.}

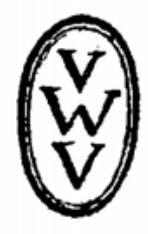

Berlin und Leipzig 1921.

Vereinigung wissenschaftlicher Verleger

Walter de Gruyter \& Co. 
